\title{
GEN Y LEADER: QUALITATIVE PHENOMENOLOGY LEADERSHIP STUDIES IN PLN APD JATENG \& DIY
}

\author{
Arsyadany Ghana Akmalaputri1 ${ }^{1}$, Ahyar Yuniawan², Indi Djastuti ${ }^{3}$ \\ ${ }_{1}^{1}$ Program Studi Magister Manajemen, Fakultas Ekonomika dan Bisnis, Universitas Diponegoro \\ 2 Program Studi Magister Manajemen, Fakultas Ekonomika dan Bisnis, Universitas Diponegoro \\ ${ }^{3}$ Program Studi Magister Manajemen, Fakultas Ekonomika dan Bisnis, Universitas Diponegoro
}

\begin{abstract}
This qualitative phenomenological study to examine and compare the style and character of Gen $Y$ leadership with the style and character of Gen X leadership in PT. Perusahaan Listrik Negara Area Pengatur Distribusi Jawa Tengah \& Daerah Istimewa Yogyakarta. The study was conducted through in-depth interviews and direct observation of selected respondents. The questions are (i) Gen X (old) leadership in preparing the cadre to deal with change, (ii) Gen Y's leadership in responding to the company's target challenge in the face of change.

The respondents of this study were the group of Gen Y leaders and the group of Gen X leaders at PT. PLN APD Jateng \& DIY. The method used is qualitative phenomenology. It is used because the purpose of this study to reveal the meaning of concept or phenomenon of experience based on the awareness that occurs in some individuals in PT. PLN APD Jateng \& DIY.

The results showed that Gen Y Leader at PT. PLN APD Jateng \& DIY provides an understanding of organizational achievement targets to staff or subordinates in typical millennial youth. In addition to coaching, mentoring and counseling $(C M C)$ and streamlining the WhatsApp Group $(W A)$, they also often hang out together. The leadership cadre preparation process continues unabated, through an active WA Group 24 hours a day, seven days a week, and 30 days in a month. While the leaders of Gen $X$ only use the CMC, code of conduct (CoC), and the person in charge (PIC) for the pattern of regeneration. The results also show that in addition to being very open to differences, Gen Y's leaders are also very tolerant of conflict in working relationships.
\end{abstract}

Key Words : Phenomenology research, organizational change, leadership of Y generation, PLN Jawa Tengah-DIY.

\section{INTRODUCTION}

PT. Perusahaan Listrik Negara (PLN) plays an important role in the Indonesian economy as a source of industrial growth, employment growth, income, foreign exchange, and regional development. Unfortunately PT. PLN has not contributed optimally yet, due to some obstacles that cause the gap between electricity growth and national electricity demand

\footnotetext{
${ }^{1}$ Corresponding author
}

PLN as one of the State-Owned Enterprises (SOEs) is given a target by the government to build 35,000 MW power plant for the next five years. The national electrification ratio is $87.5 \%$ in 2014 , and $88.3 \%$ in 2015 . Thus, the 35,000 MW power plant target is set up to achieve $97.5 \%$ electrification ratio by 2016. Until today, there is $51,000 \mathrm{MW}$ installed power plant that is managed by PLN. There are several 
barriers to completing the installation of power plant that also includes transmission and distribution line to fulfill increasing electricity demand: First, the long process of bureaucracy and negotiation for land acquisition; Second, the supply continuity of primary energy to support the operation of existing plant; Third, the adequacy of funding (Annual Report PLN, 2015).

PLN also has to deal with the issue of leadership regeneration. Personnel data of PLN (2015) indicates that from the total number of 47,594 employees, about one third belongs to Gen Y born in the 1980s and started a career at PLN since the early 2002s. The projected number of PLN employees in the next five years will also be dominated by Gen Y. The projection is calculated based on the number of PLN employees who will be retired and recruitment process with the average number of 4,600 new employees per year, or nearly ten percent of the PLN population which currently reaches 47,594 employees (processed from Annual Report PLN, 2015).

To ensure the sustainability of corporate leadership regeneration, the Talent Management System focuses on cadreading leaders implemented through a series of educational and training activities, especially for leader cadres who will occupy key organizational positions (Annual Report PLN, 2015). Organizational leadership patterns are strongly influenced by technological advances. This is because technological advances will raise the complexity of the challenge for an organization in overcoming its multi-generational skills, the level of expertise possessed by the workforce as well as promoting the development of GenerationY (Gen Y), the future leader (Dwyer, 2009).

In this context, the leader of Gen Y must be aware of the perspectives of each generation, especially those related to the work environment. The Baby Boomers tend to pay attention to their work, have a strong work ethic, and seek recognition for their work (Notter, 2005). Workers from Gen X prefer to perform their own tasks (Murphy, 2007), while Gen Y workers are less detailed about how work is done, as long as work is done on time (Kupperschmidt, 2006).

Technological developments that grow so rapidly require organizations to remain vigilant about issues related to social isolation caused by the differences in perspective and style of leadership between generations. According to Lower (2008), the technological world in which Gen Y members are born and raised, has a tendency to make their members lack of certain interpersonal skills resulting in social isolation.

PLN as an organization develops a future leadership model that can sustain organizational success, as well as to meet the needs of the organization and its employees. Therefore, organizations must continue to analyze and prepare for the emergence of Gen $Y$ as leaders in the 21st century, primarily by overcoming their social and behavioral engagement style (Levit, 2009) that occurs in the context of multigenerational labor.

In the context of Gen Y's leadership in PLN, the points to be achieved are the insights of their experiences, perspectives, and concepts related to leadership patterns and management changes. The goal is to create organizational awareness of the need to develop future Gen Y leaders who will maintain, develop, and incorporate social relationships within the organization. By analyzing and understanding the diversity caused by social generation gaps, Gen Y leaders will be better equipped to handle the social implications from the interaction between multi-generational labor relations patterns, as well as to strengthen and 
maintain an organizational competitive advantage amid rapid technological change.

Based on the above problems, namely (i) PLN experiences delays and limitations in preparing the cadre of leaders who are ready to face change; (ii) PLN faces generational and technological changes to accomplish company target to build electrical system 35.000MW, hence questions in this research are as follows:

1) How does Gen X (old) leadership react in setting up a cadre to deal with change?

2) How does Gen Y's leadership respond the company's challenge to face change?

\section{LITERATURE REVIEW}

1. Theory

One of the most striking generation because of its diversity is Gen Y, commonly known as "echo boomers" or "millennials" (Solomon, 2009). The generation born in 1977 to 1994 is known as Gen Y, or a generation that is currently 16 to 33 years old (Hawkins and Mothersbaugh, 2010). Gen $\mathrm{X}$ is a generation raised by baby boomers. According to Cascio (2013), Gen X was born in the range of 1961-1979. This generation was born in the early days of technological development and live during the cold war era. Gen X generally values education, hard work, and acknowledges the power of money.
Currently they occupy strategic positions in several organizations, both in government agencies, state-owned and private.

Some researches and journals about transgenerational leadership typically classify Gen Baby Boomers and Gen X as leaders, while Gen $\mathrm{Y}$ as the led generation. Gen Baby Boomers and Gen X are expected to be able to understand the characteristics of Gen Y, so that the organization they lead can work well. Meanwhile, there are still few studies about transgenerational leadership that focus on placing Gen Y as a leader. Gen Y's thirst for challenges characteristic makes them always look for opportunities to make their career skyrocket, while loyalty is not their top priority.

Jeswald W. Salacuse (2006) in his book Leading Leaders suggests 7 (seven) main functions of leadership that are essential for leaders to be able to lead other leaders. The seven main functions are: (a) Directing members according to organizational goals, (b) Integrating and synergizing teams, (c) mediating and managing conflicts; (d) Educating and developing subordinate competencies; (e) Motivating; (f) Representing the Organization, and (g) Building trust.

In conclusion, change is a certainty, something inevitable, but must be managed properly to achieve success.

\section{Previous Research}

Table 1

Previous Research

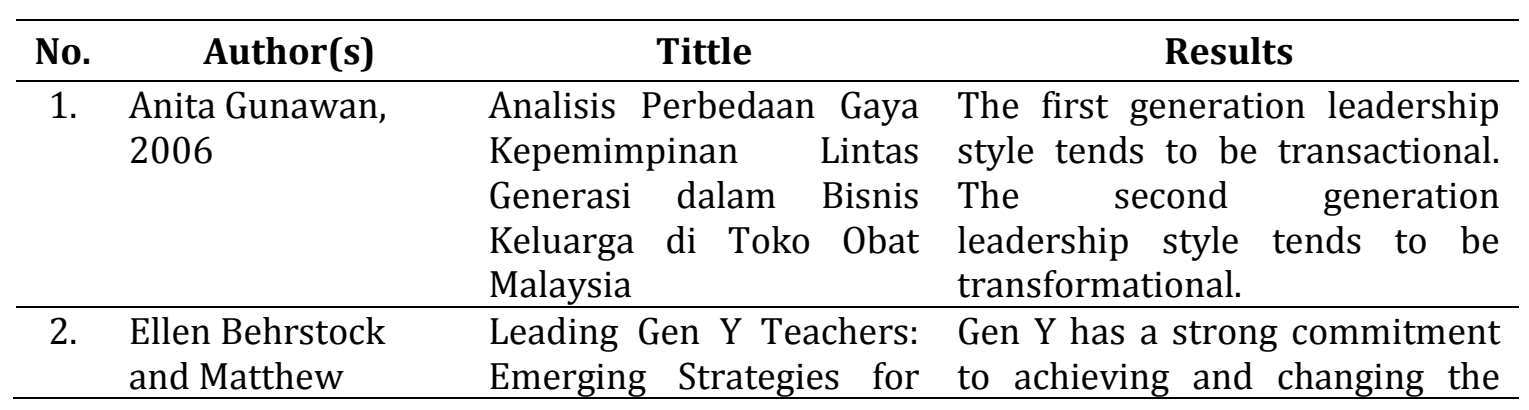




\begin{tabular}{|c|c|c|c|}
\hline No. & Author(s) & Tittle & Results \\
\hline & Clifford, 2009 & School Leaders & $\begin{array}{l}\text { world for the better. Gen Y will } \\
\text { be an educator with a strong } \\
\text { character and can help future } \\
\text { generations to lead a more } \\
\text { meaningful life. }\end{array}$ \\
\hline 3. & $\begin{array}{l}\text { Erica I. Lisbon, } \\
2010\end{array}$ & $\begin{array}{l}\text { A Study of Leadership } \\
\text { Preference by Generation }\end{array}$ & $\begin{array}{l}\text { Leaders must adapt appropriate } \\
\text { approaches to maintain the best } \\
\text { talent in the workforce across } \\
\text { multiple generations. }\end{array}$ \\
\hline 4. & Alfida Fawazi, 2012 & \begin{tabular}{lrr} 
Analisis & \multicolumn{2}{c}{ Pengaruh } \\
Ekspektasi & Kerja Gen X \\
dan Gen Y terhadap \\
Efektivitas & \multicolumn{2}{c}{ Strategi } \\
Rekrutmen di PT. \\
Samudera Indonesia.
\end{tabular} & $\begin{array}{l}\text { Working expectations of } \mathrm{X} \text { and } \mathrm{Y} \\
\text { generation have a significant } \\
\text { influence on the effectiveness of } \\
\text { recruitment strategy in PT. } \\
\text { Samudera Indonesia. }\end{array}$ \\
\hline 5. & $\begin{array}{l}\text { Camille Ramirez, } \\
2012\end{array}$ & $\begin{array}{l}\text { Generation Y Leadership: } \\
\text { A Qualitative } \\
\text { Phenomenological Study } \\
\text { of Virtual Socialization } \\
\text { Relationship }\end{array}$ & $\begin{array}{l}\text { Y generation leaders must be } \\
\text { able to prepare leadership by } \\
\text { adapting and changing as multi- } \\
\text { generational needs in the work } \\
\text { environment. }\end{array}$ \\
\hline 6. & $\begin{array}{l}\text { Irving Luntungan, } \\
\text { Ade Vitalaya, S. } \\
\text { Hubbies, Euis } \\
\text { Sunarti, Agus } \\
\text { Maulana, } 2014\end{array}$ & $\begin{array}{llll}\text { Strategi } & & \text { Pengelolaan } \\
\text { Generasi } & \text { Y } & \text { di } & \text { Industri } \\
\text { Perbankan } & & \\
\end{array}$ & $\begin{array}{l}\text { The importance of proactive } \\
\text { attitudes to approach Y } \\
\text { generation as early as possible to } \\
\text { ensure their involvement in the } \\
\text { banking industry. }\end{array}$ \\
\hline
\end{tabular}




\section{Research Framework}

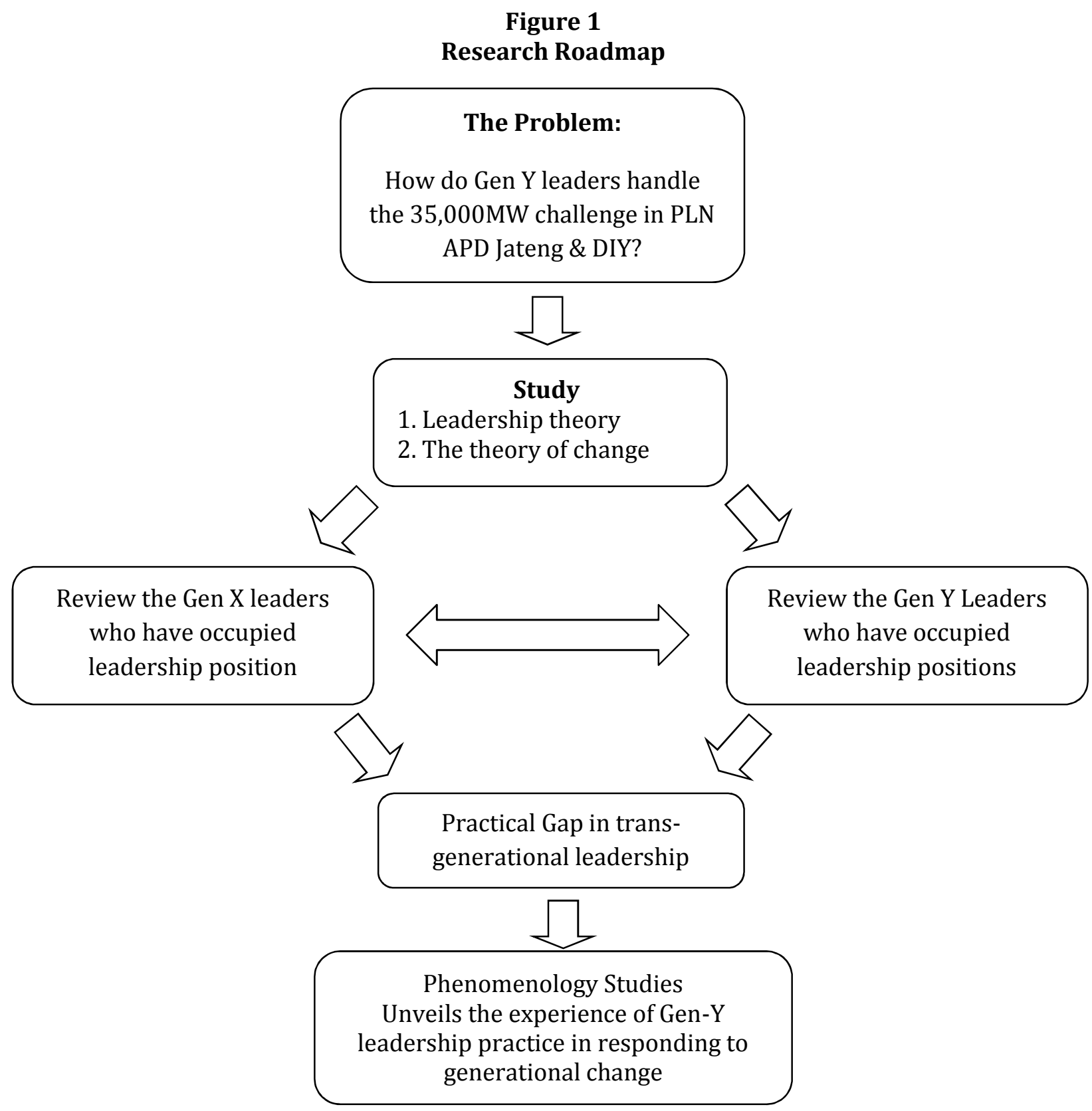

III. RESEARCH METHOD

1. Research Approach and Type of Research

This study uses a qualitative research approach with phenomenological design to match leadership research result with items in research question. The qualitative approach of phenomenology is chosen to illustrate the life experiences, perspectives, and concepts of future Gen Y leaders prepared for leadership roles, related to their social interaction within their respective 
organizations (Leedy \& Ormrod, 2010; Shank, 2006).

\section{Research Focus}

This research focuses on the leadership of Gen $\mathrm{Y}$ in continuing the leadership relay in PLN, especially PLN APD Jateng \& DIY, on a mission to complete the construction of 35,000 MW power plants in Indonesia along with the increasing power transmission and distribution facilities.

\section{Data Source and Sample}

This study takes sample from 4 Gen Y Manager Assistants and 3 Gen X employees occupying structural positions in PLN APD JTY, utilizing key informants to deliver researchers to group members Or the person to whom it is concerned.

\section{Data Collection Method}

In qualitative research, the main data collection used is participant observation techniques, in-depth interview, documentation study, and the combination of all three or triangulation (Sugiyono, 2011).
According to Paton (2002), there are three ways of collecting qualitative data, i.e. interviews, observation, and document studies.

\section{Data Validation}

The validation of research data is tested with triangulation honesty of researchers. Triangulation honesty of researchers is used to test the subjectivity, honesty, and the ability to record data in research. The method is conducted by performing member checks on the validation table as a verification step of interview results and then signed by the source.

\section{Analysis Method}

Data analysis technique used in this research is qualitative data analysis, following the concept given by Miles, Huberman, and Spredley (Sugiyono, 2011). The analysis steps are shown in the following figure:

Figure 2

Data Analysis Process

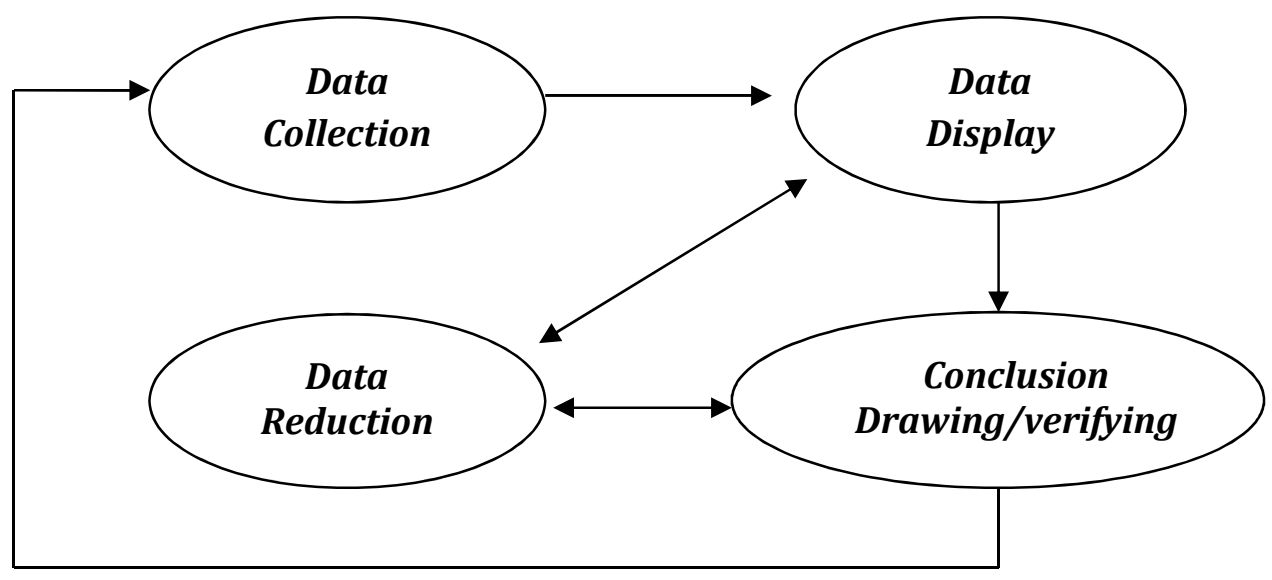




\section{RESULTS AND DISCUSSION}

The results of field studies to the research variables, i.e. the leadership of Gen X (the old one) in preparing the cadre to deal with change, and the leadership of Gen Y in answering the company's target challenge in the face of change, are explained below. The study variable uses the leadership functions delivered by Jeswald W. Salacuse (2006) as described above.

\section{How to Lead}

Gen Y Leaders at PT. PLN APD Jateng \& DIY initiated a plan by first evaluating the previous performance, whether there is still a gap in the work. After that they arrange new plans according to organizational goals, break them down to all members of the organization, unify perceptions, implement them together, and control the performance at every stage of the work. Their communication way is vastly open, always two-ways, persuasive, non-authoritarian and does not impose an opinion. Code of Conduct (CoC), hang out together, and Whats App Group (WA) are used optimally as communication tools to achieve organizational goals. The target performances of each job are monitored in real time through the WA Group.

Gen X leaders start to lead by first setting clear goals and targets, assuring staff and subordinates that leaders always back them up, listening to staff and subordinates through short meetings, and giving credit, compliment and rewards when they achieve the target. This leadership pattern tends to be transactional. Especially for subordinates who are not in line with the goals set will be given explanation, training and motivation. But there is no time to help subordinates, except to tell them what to do, and then followed by coaching.

\section{How to Synergize the Team}

To build and synergize a team, Gen Y leaders at PT. PLN APD Jateng \& DIY always start by requesting input or feedback from all members, and accommodating all the opinions before finally made a plan. Similar to their method to direct members achieving organizational goals, Gen Y leaders initiate by fact finding and / or input from all members, discussing them openly, using less serious communication styles and no hard feeling, continuously growing a sense of kinship and trust, and always taking care of it. They optimize CoC, WA Group, hang out outside, dine together or just watch movie together to build and synergize a solid team. In short, Gen Y's group of leaders always build and synergize a team through two way communication, to develop a family-like atmosphere at work that makes it a solid team.

The most important thing for Gen $\mathrm{X}$ leaders is the ability to unify the different types of people in a team, because each team member has their own way to communicate. Assuming the team is a place to share job and happiness, this group tends to avoid harsh words that are considered to hurt others in building relationships. On the other hand Gen $\mathrm{X}$ leaders do not hesitate to make decisions immediately, regardless of staff and subordinates' objections.

\section{How to Manage Conflict}

Gen Y Leader at PT. PLN APD Jateng \& DIY views conflict as something that must exist, and should not be avoided. Conflict according to them will only further refine the decision. It's just that the conflict must be resolved and not allowed to drag on. There is a time limit for completion. Although the group is "relying" on the WA Group in applying POAC (planning, organizing, actuating and controlling) and 
communicating with all members, but to resolve conflicts they still see face-to-face roles as important, especially to avoid misperceptions. This group also tends to use practical ways to quickly resolve conflicts that have been categorized as deadlocks. In addition to not hesitate to involve superiors, more skilled people, and job consultants, also do not hesitate to use the legal path. Gen Y's leader still avoids authoritarian ways to resolve a conflict.

Gen X Leaders in general also recognize that conflicts in work relationships will always be there, so that conflicts must be dealt with. Yet Gen X groups prefer it if there is no conflict in the workplace. This group will precipitate conflicts that have been entered at the deadlock stage, to then continue the mediation the next day. Although face-to-face roles are crucial to resolve conflicts, they see face-to-face rather than as a necessity. More than that, Gen X Leaders tend to limit the involvement of people in resolving conflicts.

\section{How to Respond to Change}

Although in general the ability of staff or team members is adequate, but the leader of Gen Y at PT. PLN Central Java \& DIY still assume that the staff's ability to keep improving. This group always thinks that an organization will always evolve and keep changing, following the changes and the development of the times. Therefore, the performance of future team members must also follow the changes and developments that will be faced by the organization. Gen Y Leaders anticipate future changes and developments, not just by training, refreshing knowledge, and knowledge sharing, but also by cross-knowledge and cross-work. This method is positively responded because in addition to allowing all members to acquire new knowledge, it can also compare the work to which they are responsible for the work that becomes the responsibility of other fields.

Leader Gen X does not address specific changes. They even see the competence of staff or subordinates is good and is in accordance with the needs of the organization. The group conducts training, coaching and monitoring as per the organization's needs. Change is addressed naturally without any special treatment.

\section{How to Motivate}

Patterns of cadreing or the way of Gen Y leaders in PT. PLN APD Jateng \& DIY provides motivation to subordinates is to always implement CMC (coaching, mentoring, counceling). CMCs are not always carried out in the office, but are often done outside the office. CMC for the development of an organization is very important, because it is associated with the pattern of leadership cadre. Although the new CMC is routinely implemented for all team members, it does not cover the possibility of CMC implementation that is personal. It is primarily intended for individuals who immediately get promoted. In the future CMC that is personal will also routine.

The mode of motivation or regeneration pattern prepared by the Gen X group of leaders to staff or subordinates who have not been competent only at certain times or at certain times. This group monitors and monitors the performance of staff or subordinates, according to the interests and needs of the organization.

\section{Representing Organization}

Gen Y's leader group at PT. PLN APD Jateng \& DIY establish social relationships as a representation of organizations with all stakeholders, both inside and outside PLN, customers, partners or vendors, and 
academics. With customers for example, to know their level of satisfaction. With academics related to corporate performance research or research that supports the effectiveness of company performance. In carrying out this function, the leader of Gen Y must still be professional, in the sense of having to uphold professional ethics by sticking to code of conduct (CoC).

The leader of Gen X group is not too strict in applying professional ethics. On the contrary, this group tends to be pliable. This is evident from the statement of two of the three informants of this group who stated that do not know any special rules in interacting with outsiders. Also do not know there are sanctions that regulate the interaction with outsiders.

\section{Building Trust}

Gen Y Leader at PT. PLN APD Jateng \& DIY build trust by always increasing the competence of staff or subordinates. Out, among other things, to develop the level of customer trust. Into, inter alia, to improve management trust. They build openness or transparency with honesty in deliver report. They are always open to suggestions and criticism, for better work or performance. The suggestions and criticism can even come from other parts. They also ensure all info shared to all staff or subordinates, and make sure all events have record.

Leaders of the Gen X group are very confident and trust that their staff or subordinates are always consistent with the company's code of conduct (CoC), and must adhere to firm rules, always open and transparent. The benchmark employed by the Gen $\mathrm{X}$ group is the absence of office entry and exit hours.

\section{CONCLUSION, LIMITATION, AND FUTURE RESEARCH AGENDA}

\section{Conclusion}

Based on the research and discussion of Gen Y leadership at PT. PT. PLN APD Jateng and DIY, according to qualitative research method of phenomenology, can be concluded as follows:

1) The Gen $Y$ Leader provides an understanding of the organization's performance targets to staff or subordinates in the typical way of the millennial youth. In addition to coaching, mentoring and concelling (CMC) and streamlining the WhatsApp Group (WA), they also often hang out together. The leadership cadre preparation process also continues to occur, let alone the WA Group is active 24 hours a day, seven days a week, and 30 days a month. In addition to the process of cadreing running non-stop, all problems are also directly discussed and resolated via the WA Group in real time. This is in contrast to Gen X leaders who rely solely on approaches through CMC, CoC (code of conduct), and PIC (person in charge), giving praise, reward and reward to staff or subordinates who are considered to have exceeded the target.

2) The leader of Gen Y opens opportunities for subordinates who are inconsistent with the decisions taken for open dialogue, reasoning for his disagreements, even the chances of trying to carry out the opinions he believes to be true, to the extent that they do not conflict with the lines or rules of the company. This is in contrast to the leader of Gen $\mathrm{X}$ who is quite accommodative to subordinates who disagree to explain the reasons for disagreement, but does not provide 
opportunities or opportunities to try different opinions. Every time a disagreement occurs, Gen X's leader always returns to the normative rules of the company.

3) The leader of Gen Y in strongly tolerates conflict in working relationships. For them, conflict is not something to be avoided, conflict is just to perfect a decision. In resolving potential deadlock conflicts, Gen Y's leader does not hesitate to invite third parties who are judged to be more expert and competent with the issues. Leader Gen Y views an important face-to-face role to resolve the conflict, whereas Gen $\mathrm{X}$ leaders who initially sow conflict, and view the conflict as unnecessary, think face-to-face is not a necessity. On the other hand, Gen X's leaders feel quite satisfied with the ability of subordinates, whereas Gen Y's leader always feels something is lacking in subordinate skills, because the leader of Gen Y sees organization as dynamic, because it requires continuous learning.

\section{Implications of Managerial Policies}

1) Gen $Y$ has a more democratic, dynamic, transparent leadership style, has a strong commitment to achievement, and adheres to professional ethics. Although it tends not easy to manage, but Gen Y is a sociable, loyal, and adaptable in facing challenges and changes in the environment. Gen $\mathrm{Y}$ is raised in a social network-based technology that is more prominent than face-to-face social interaction. Therefore, PT. PLN, in addition to having to conform to the way of approach that suits the character of Gen Y, also need to provide different flexibility to them as long as it is still constructive and does not violate the company's code of conduct.

2) PLN must begin to accommodate the culture that accompanies the growth of technologically-savy Y Gen, want to do many things at the same time, like to move together, be very confident, and not easily moved to do things. Things that are not understood intent and purpose. Cultural disparities that occur between generations should not be exacerbated by communication gaps. Basically Gen Y is "easily understood" person of logical origin.

\section{Limitation}

Phenomenological research is very subjective because it is based only on the experiences of certain people so it can't be generalized to different conditions and environments.

\section{Future Research Agenda}

For future research in order to describe the condition of an organization more broadly and deeply, future research is suggested to use ethnographic, and / or quantitative methods that can be used to generalize in making decisions in general. 


\section{REFERENCES}

Arikunto, Suharsimi, 2002, Metodologi Penelitian, Penerbit PT. Rineka Cipta, Jakarta.

Arikunto, Suharsimi, 2006, Prosedur Penelitian: Suatu Pendekatan Praktek, Edisi Revisi, PT. Rineka Cipta, Jakarta.

Baggot, C. A, 2009,If We Build It, They Will Come,National Civic Review, 98(3),pp. 30-33

Bennis, W, 2009.,On Becaming a Leaser. The Leadership Claasic. Basic Books.

Berger, L. A., 1994, Change Management, In The Change Management Handbook: A Road Map to Corporate Transformation, Edited by Berger, Sikora, and Berger McGraw-Hill

Burnes, B., 2000, Managing Change: A Strategic Approach to Organisational Dynamics, Third Edition, Prentice Hall

Barker, R. T. \& Camarata, M. R., 1998, The Role of Communication in Creating and Maintaining a Learning Organization: Preconditions, Indicators, and Disciplines, The Journal of Business Communication, vol. 35, no. 4, Oct

Cascio, W. F, 2000,Managing Virtual Workplace, Academy of Management Executive, 14(3), pp.81-90.

Clark, Clarkm and Crossley, 2010, Developing Multidimentional Trust Without Touch In Virtual Team.Marketing Management Journal, 20, 177-179.

Creswell, John W, 2005, Metode Penelitian Kualitatif, Pustaka Pelajar, Yogyakarta.

Daymon, C., \& Holloway, I, 2011, Qualitative Reasearch Methods ini Public Relation and Marketing Communications, Routledge Taylor \& Francis Group, London and New York.

Dawson, S., 1996, Analysing Organisations, Third Edition, Macmillan Business.

Denzin, K. N., \& Lincolin, S. Y. 2005, Qualitative Research (3rd ed., Vol. 3). California : Sage Publications. http://doi.org/10.1017/CB09781107415324.004

DeRosa, D., Hantula, D.A., Kock, N., D'Acry J., 2004, Trust and leadership in virtual teamwork: A media naturalness perspective, Human Resource Management, p.219-232.

Draft, Richard L, 2005, The leadership experience, page 5.

Drecker, P., 2011, People and Performance: The Best of Peter Druke on Management. New York: Routledge.

Duncan, T. \& Moriarty, S. E., 1998, A Communication-Based Marketing Model for Managing Relationships, Journal of Marketing, vol. 62, iss. 2, Apr 
Dwyer, Judith. R. J, 2009,Prepare for the Impact of the Multi-Generational Workforce!,Transforming Government People, Process and Policy, 3(2), pp. 101-110

Erickson, T. J, 2009, Finally, Gen X Takes Over,Harvard BusinessReview, 11 January

Handoko, T.H, 2001, Manajemen Personalia dan Sumber Daya Manusia, BPFE, Yogyakarta

Harsiwi, 2001, Hubungan Kepemimpinan Transformasial dan Karakteristik Personal

Pemimpin, Jurnal Bisnis dan Ekonomi, Program Pasca Sarjana Universitas Atna Jaya, Vol 5, No. 1, Juni, Yogyakarta

Hasibuan, Akmaluddin, 2012, Manajemen Perubahan, CV. Andi Offset,Yogyakarta.

Hawkins, D.I., dan Mothersbaugh, D.L., 2010, Consumer Behavior: Building Marketing Strategy, 11th edition, McGraw-Hill, Irwin

Howe, N. \& Strauss, W., 1991, Generations: The History of America's Future, 1584 to 2069, William Morrow Paperbacks: New York City

Jeanne Meister, Karie Willyerd, 2010,Mentoring Millennials, Harvard Business Review Magazine: http://hbr.org/2010/05/mentoring-millennials/ar/1

Kabul Wahyu Utomo,2002. Kepemimpinan dan Pengaruhnya terhadap Perilaku Citizenship (OCB), Kepuasan Kerja dan Perilaku Organisasional, Jurnal Riset Ekonomi dan Manajemen, Volume 2 No.2, Mei

Kotter, P, J, 1995, Leading Change: Whay Transformation Fail. Leadership, 12.

Kupperschmidt, B. R, 2006,Addressing Multi-Generational Conflict: Mutual Respect and Carefronting as Strategy, The Online Journal of Issues in Nursing, 11(2), manuscript 3

Kreitner, R. \& Kinicki, A., 1995, Organizational Behavior, Third Edition, Irwin

Lancaster, L. C, 2004, When Generations Collide: How to Solve the GenerationalPuzzle at Wor, The Management Forum Series,March 17

Levit, A, 2009,The Future World of Work: A GenXer's Perspectives, The Futurist, SeptemberOctober , pp. 39

Lexy J. Moleong, 2005, Metodologi penelitian kualitatif, Bandung, PT. Remaja Rosdakarya, 4

Lichtenstein, B. B., 2000, Self-Organized Transitions: A Pattern amid the Chaos of Transformative Change, Academy of Management Executive, vol. 14, no. 4

Lofland, J. 1974. Styles of Reporting Qualitative Field Research. American Sociological Assotiation Springer, 9 (3), 101-111.

Lower, J, 2008, Brace Yourself Here Comes Generation Y, Critical Care Nurse, 28(5),October,pp. 80-84 
Markplus Institute, 2015, Tips Mengelola Gem Y, created Raditya Tanu Hutama, http://www.markplusinstitute.com/who we are/detail article/33, 29 November 2016

Markplus Institute, 2016, https://www.markplusinstitute.com/training/detail training/ 136,29 November 2016

McDonald, J. M., 2000, Managing Rapid Change: From Theory to Practice, Southern Business Review, Spring

McDonald, P, 2008,The Multi-Generational Workforce,Internal Auditor, 65(5), pp.60-67

Murphy, S.A, 2007, Leading a Multi-Generational Workforce,AARP

Notter, J, 2005,Why Generations Matter, and Why They Don't: The Business Realities ofDiversity in the Workplace,Symposium conducted at the meeting of ASAE/Center forAssociation Leadership, May 23

P.M. Podsakoff, S.B. Mackenzie, R.H. Moorman, and R. Fetter, Transformational Leader Behaviors and Their Effects on Followers' Trust in Leader, Satisfaction, and Organizational Citizenship Behaviors, Leadership Quarterly 1, no. 2 (1990), pp. 107-142

Pelton, Lou E\& True, Sheb L, 2004,Teaching Business Ethics: Why Gen Y?,Marketing Education ReviewVol.14 (3),Taylor \& Francis Journal

Prensky, M, 2001,Digital Natives, Digital Immigrants, Part II: Do TheyReally Think Differently?,0n the Horizon, 9(6), pp. 1-9

N. Renaldi S, 2016, Pemikiran Seorang Manusia, Tajuk Ganesha ITB

Tulgan, B, 2004,Trends Point to a Dramatic Generational Shift and the Future Workforce,Employment Relations Today, 30(4),pp. 23-31

Solomon, M.R., 2009, Consumer Behavior Buying, Having, and Being, New Jersey : Pearson Education Inc

Sugiyono, 2008, MetodePenelitian Kunatitatif Kualitatif dan R\&D, Alfabeta, Bandung.

Snyder, B, 2003,Teams that Span Time Zones Face New Work Rules,Stanford BusinessMagazine,May, pp. 3-15

Stevens, R. H, 2010,Managing Human Capital: How to Use Knowledge Management to TransferKnowledge in Today's Multi-Generational Workforce,International Business Research,3(3), pp. 77-83

Vaille, P. B., 1989, Managing as a Performing Art: New Ideas for a World of Chaotic Change, Jossey-Bass 
Vega, G., \& Brennan, L. M., 2000, Isolation and Technology: The Human disconnect, Jurnal of Organization Change Management, 13 (5), 468-481

Yukl, G. 2010. Leadership in Organizations. Retrieved from http:/files.liderancaecoaching.webnode.com/200000015-31f5732fb3/media-F7B-97randd-leaders-business-yukl.pdf.

Zetlin, M, 1992,Young Managers Face a Generation Gap,Management Review, 81(1), pp. 10 15 